\title{
Perangkap Industri Budaya dalam Desain Lanskap di Pulau Bali
}

\author{
NANIEK KOHDRATA \\ Program Studi Arsitektur Pertamanan, Fakukta Pertanian, Universitas Udayana \\ Gedung Agrokompleks It.2, Jl. PB Sudirman, Denpasar, 80236, Indonesia \\ *E-mail: naniek_kohdrata@unud.ac.id
}

\begin{abstract}
A Cultural Industry Trap on Landscape Design in Bali Island

Landscape architecture is a field in applied science that characterized by its multi-discipline approaches. However, people mostly correlate landscape architecture as a field of science and profession to deal with design dan art, especially with gardens. This paper, will discusse the issue of landscape design in Bali from the perspective of cultural studies. Landscape design activities are include but not limited to material objects, such as parks, streetscapes, cityscapes, and other landscape design products. It seems that present landscape design tastes have started from the western world. One of the landscape architects who criticize landscape design is Marc Treib. He primarily criticized the landscape design discourse occurring in the United States. Treib three canons about landscape tastes have shown applicable to recent landscape design conditions in Bali Island. Especially because there are still many landscape architects from abroad have been working in Indonesia projects, as well as landscape architects graduates of America and other western countries. Bali is a heaven for those landscape architects to set their status of fame for it provides amount of opportunities in hotel and resort landscape design and private villas gardens as well. The influence of scholars and design values emerge in Bali, especially in the public and semi-public sectors is colored by Western design "ideologies".
\end{abstract}

Keywords: landscape design, design taste, design discourse, western design ideology.

\section{Pendahuluan}

Arsitektur lanskap sebagai suatu bidang ilmu, memiliki karakeristik keilmuan yang multi-disiplin. Meskipun diawali dengan kata arsitektur, perlu diingat pula bahwa terdapat kata lanskap yang mengikutinya. Masyarakat secara umum sering mempersepsikan arsitektur lanskap sebagai bidang ilmu maupun profesi yang berkaitan dengan desain dan seni. Anggapan tersebut tidak sepenuhnya salah, walaupun juga tak dapat dikatakan sepenuhnya benar. Arsitektur lanskap memiliki karakteristik keilmuan yang multi-disiplin. Kata arsitektur yang mengawali hendaknya dimaknai sebagai "menata" atau "mengatur" sesuatu. Hal yang diatur atau ditata tidak harus bangunan, walaupun media yang 
dipergunakan adalah obyek material. Jackson (1980) dan Whythe (2002) mengemukakan lanskap sebagai media berlangsungnya interaksi antara manusia dengan lingkungan dalam jangka panjang dan secara konsisten mengalami perubahan dengan berjalannya waktu. Whythe (2002) dengan lebih spesifik mengatakan bahwa lanskap mencakup apa yang terlihat kasat mata (tangible) sebagai suatu produk budaya dan sosial (manusia) dan juga segala sesuatu yang tak kasat mata (intangible) yang terjadi dari jalinan hubungan antar variabel-variabel sosial dan budaya dalam suatu lanskap.

Menyandingkan kata Arsitektur dan Lanskap mengarahkan kita untuk menyadari bahwa ada upaya menata (to arrange) dalam suatu lanskap. Terminologi yang umum dipakai untuk aktivitas "menata" itu adalah desain. Imam Buchori Zainuddin, guru besar bidang Desain dari ITB, mendeskripsikan kegiatan mendesain sebagai upaya kreatif dalam rangka pencarian solusi alternatif baru yang lebih baik dari solusi sebelumnya sesuai tuntutan kebutuhan yang selalu berubah. Desain merupakan suatu kegiatan yang menuntut hadirnya kreatifitas dan imajinasi sang pelaku dalam upayanya menawarkan mutu estetis. Alur pemikiran mengenai desain dan estetika inilah yang menghasilkan pemahaman bahwa desain itu adalah seni (Damajani dan Larasati, 2010).

Dalam tulisan ini, akan didiskusi persoalan desain lanskap dari perspektif industri budaya. Salah satu dampak dari kegiatan desain lanskap adalah obyek material, seperti taman (park, garden), lanskap kota, lanskap jalan, dan berbagai hasil desain lainnya. Permasalahan mengenai selera desain lanskap, terutama tentang hasil-hasil desain, bermula dari dunia barat. Salah satu arsitek lanskap yang mengkritisi desain lanskap adalah Marc Treib. la terutama mengkritisi wacana desain lanskap yang terjadi di Amerika Serikat. Wacana kritis desain lanskap yang dilontarkan oleh Treib cukup relevan untuk dipakai sebagai kacamata untuk mengkritisi desain lanskap yang ada Indonesia. Terutama karena masih banyaknya arsitek-arsitek lanskap dari luar negeri yang berprofesi di Indonesia maupun arsitek-arsitek lanskap lulusan Amerika dan Negara-negara barat lain. Pengaruh keilmuan dan nilai-nilai desain yang muncul di Indonesia, terutama di sektorsektor publik dan semi-publik diwarnai oleh "ideologi" desain Barat.

\section{Metode}

Tulisan ini mencoba untuk menelaah praktik-praktik desain lanskap (karya taman dan lanskap) yang dilakukan oleh arsitek-arsitek lanskap dengan menggunakan paradigma kajian budaya. Subyek tulisan ini adalah karya yang dihasilkan oleh beberapa arsitek lanskap sebagai pintu masuk untuk melihat fenomena desain yang dihasilkan pada sekitar akhir abad ke-20 dan awal abad ke-21 ini. Tulisan ini bukan dimaksudkan untuk mencari bukti-bukti empiris akan tren desain, bahkan tidak bertujuan untuk menghakimi nilai "estetika" dari suatu desain taman atau lanskap. Artikel ini mencoba memberikan alternatif untuk melihat hasil-hasil karya desain arsitektural lanskap dari perspektif kajian kritis. 


\section{Hasil dan Pembahasan}

\subsection{Desain Lanskap dalam Perspektif Kajian Budaya}

Hidup manusia dikelilingi oleh hal-hal yang mendapat sentuhan desain dengan kadar dan intensitas bervariasi, mulai dari yang paling rendah hingga yang intens. Salah satu bagian kecil dari hal yang didesain tersebut adalah lanskap yang mencakup diantaranya taman publik, semi-publik (seperti taman hotel, resor, institusi), taman pribadi, median dan bahu jalan, serta ruang-ruang terdesain lain. Marc Treib (1993) menyebutkan adanya dua cara pandang terhadap lanskap. Pertama adalah lanskap yang didesain oleh arsitek atau desainer lanskap yang menerapkan dan menetapkan standar dan "kelas" desain pada obyek desainnya. Lanskap model kedua dalah yang tidak didesain oleh para professional tersebut, tetapi desain yang dilakukan oleh masyarakat, yang juga memiliki selera dan standar desain sendiri yang mewakili selera mereka. Desain lanskap juga membahas persoalan selera yang sejalan dengan apa yang dikemukan oleh teori Bourdieu bahwa selera merupakan suatu karya seni dalam konteks dan kondisi tertentu. Implikasi dari pandangan Bourdieu pada desain lanskap adalah semua desain lanskap adalah karya seni, terlepas dari siapa karya seni tersebut berasal.

Bagi para professional di bidang lanskap, selera merupakan hal penting yang menjadi perhatian mereka. Lanskap yang populer dan sesuai selera publik menjadi aspek penting bagi arsitek lanskap untuk diperhatikan apabila mereka ingin diakui eksistensinya. Atau sebaliknya, apabila mereka mengabaikan selera publik, maka stempel eksentrik atau "tidak nyambung" (irrelevant) akan disematkan di dahi mereka. Memang bukanlah hal yang mudah membahasa masalah selera. Seperti yang dikatakan oleh Treib bahwa akar permasalahannya ada pada semantik. Frasa seperti "selera bagus" dan "selera jelek", "selera tinggi" dan "selera rendah" sarat dengan muatan ekspresi dan makna yang tendensius. Terlebih apabila frasa tersebut dipergunakan oleh kelompok yang menganggap dirinya memiliki "selera tinggi" dan menyematkan identitas "berselera rendah" pada kelompok yang lain. Penggunaan frasa tersebut menciptakan perbedaan status dalam kelompok sosial yang mengesankan dikotomi antara kelompok elit dan non-elit, kelompok penting dan tidak-penting. Seperti yang dikatakan Bourdieu bahwa selera dapat dipergunakan sebagai alat yang penanda kelas. Selera seseorang akan akan memberikan gambaran dan status dan posisi seseorang dari cara ia mengkonsumsi penanda tersebut. Penanda yang dikonsumsi itu kemudian mengalami transformasi diri menjadi perilaku dan diterima sepenuhnya dalam hidup orang itu. Perilaku itu diikuti oleh serangkaian pembedaan dalam konteks pengkelasan secara vertical dengan berbagai macam model dan cara, semisal awal atau akhir, domestik atau skolastik, kelas-kelas individu berilmu atau sebaliknya, dan hal-hal sejenis yang bersifat duniawi.

Persoalan yang muncul kemudian dalam dunia desain lanskap adalah peletakan posisi arsitek atau desainer lanskap, yang notabene merupakan lulusan sekolah dan perguruan tinggi ilmu arsitektur lanskap, lebih tinggi dari individu yang melakukan pekerjaan yang sama namun tanpa embel-embel gelar dan dokumen-dokumen formal yang "mengesahkan" dirinya berada dalam kelas profesi tersebut. 
Dalam kasus selera desain lanskap popular di Amerika, Treib merangkumnya dalam tiga kanon atau "hukum" mengenai selera desain. Pertama adalah bahwa selera popular bukanlah masalah sepele, karena masalah selera adalah bagian mendasar bagi semua budaya, serta merupakan hal krusial yang dipergunakan oleh suatu bangsa dan juga budaya untuk mengidentifikasikan diri dari bangsa dan budaya lainnya. Kanon kedua adalah bahawa selera lanskap, sama seperti selera lainnya, menampakkan dirinya dalam dua level yang berbeda pada budaya manapun. Level pertama adalah yang bersifat fundamental (mendasar, kekal), sementara level kedua memiliki sifat ephemeral (tidak kekal, sementara). Ketiga adalah kanon yang menyebutkan bahwa lanskap budaya terbagi dalam dua kategori ruang: satu adalah ruang dimana standar-standar selera secara rutin dimunculkan dan digugah, ruang kedua adalah ruang dimana hal-hal yang terdapat pada ruang pertama tidak dilakukan.

Kanon pertama menunjukkan pentingnya identitas bagi manusia sebagai salah satu bentuk mata rantai yang mengikat dirinya sebagai mahluk hidup yang terikat dengan komunitasnya. Treib mengatakan bahwa seseorang tidak akan dapat memahami suatu budaya tanpa memahami ide kolektif dari komunitas budaya itu mengenai hal-hal yang termasuk indah atau tidak, selera yang baik atau buruk, dan seterusnya. Selera dalam lanskap merupakan bagian penting dalam suatu sistem yang lebih besar karena lanskap ada dimana-mana dan juga ia terlihat. Kanon pertama Treib juga memberikan implikasi selera popular sebagai indikasi budaya yang mendasari suatu bangsa. Jika kita yakin bahwa selera dapat mengidentifikasi budaya, sub-budaya, dan bangsa, maka perubahan selera yang terjadi pada suatu bangsa sama artinya dengan telah terjadinya perubahan budaya yang mendasar pada bangsa itu.

Segala jenis budaya dan sub-budaya (sub culture) menyatu dan juga sekaligus terbagi-bagi oleh sistem-sistem metafisik dan etik. Budaya dan sub-budaya terikat karena kemiripan namun juga terbagi-bagi karena sistem estetika yang salah satunya menggunakan perpanjangan tangan "selera" untuk mendeskripsikan estetika itu. Selera sering diungkapkan lewat bahasa yang terdengar sepele. Walaupun pada kenyataannya hal-hal yang diungkapkan itu sama sekali tidak sepele apabila diaplikasikan pada pemberian identitas pada manusia yang merupakan anggota dari suatu budaya atau subbudaya. Selera estetika desain lanskap diupamakan dengan penggunaan bahasa, dialek, dan aksen yang secara langsung akan mengidentifikasikan diri sebagai anggota dari sejumlah kelompok-kelompok budaya atau bangsa.

Selera desain lanskap selalu menjadi bahasan menarik dalam bidang arsitektur lanskap karena secara langsung memperlihatkan keanggotaan individu-individu dalam kelompok sub-budaya tertentu dengan penampakan yang mengikat. Kita biasanya akan diliputi oleh pertanyaan-pertanyaan seperti, 'taman seperti apa yang bagus untuk rumah?', 'rumah model apa yang sesuai untuk tempat tinggal?', 'desain taman median jalan yang bagaimana yang bagus untuk kota kita?', demikian seterusnya pertanyaan muncul bertubitubi mengenai desain lanskap yang 'bagus' dan 'baik'. Secara individual, jawaban kita terhadap pertanyaan-pertanyaan tersebut mungkin terdengar sepele atau mungkin istimewa, yang apabila dipadukan maka selera-selera kita akan mengidentifikasi 
komunitas dimana kita menjadi anggota. Artinya adalah jawaban kita menjadi semacam kunci penentu identitas budaya kita. Meminjam ungkapan dari Gaylord Hauser (dalam Treib, 1993) yang mengatakan "Kamu adalah apa yang kamu makan (You are what you eat)". Ungkapan itu cukup selaras dengan apa yang terjadi dalam desain lanskap, yaitu "selera lanskap anda akan menunjukkan pada semua orang siapa diri anda". Identitas itu sebenarnya sama sekali tidak ada kaitannya dengan status seseorang dalam konteks vertikalitas kemasyarakatan. Mungkin lebih sesuai bila dikatakan sebagai posisi relatif seseorang terhadap yang lainnya dalam satu himpunan yang bersifat horisontal yang sejajar.

Kanon kedua memberikan penjelasan bahwa selera yang fundamental memiliki sifat sulit diubah, bahkan dapat dikatakan tidak dapat ditiadakan. Selera fundamental merupakan bagian dari kosmologi dasar suatu bangsa yang melintasi ruang, waktu, dan kelas. Sebaliknya dengan selera yang bersifat ephemeral, ia lincah dan akan terus berubah dari waktu ke waktu, berbeda dari satu tempat ke tempat lainnya, dan juga dapat mengidentifikasi sub-kelompok dalam kerangaka budaya yang lebih besar. Karakter demikian menyebabkan, selerea ephemeral sangat rentan atau mudah untuk dimanipulasi, berbeda sebaliknya dengan selera fundamental. Selera ephemeral mengalir dan berubahubah dengan relatif cepat dari waktu-waktu, sementara selera fundamental/primer lebih bersifat menetap karena berakar dari budaya kolektif yang terinternalisasi dalam anggota budaya itu. Seandainya pun terjadi pergeseran atau perubahan budaya, maka hal itu akan susah teramati dalam hitungan seumur hidup manusia. Rentang waktu yang diperlukan untuk mengamati perubahan tersebut melebihi umur seorang manusia.

Kanon ketiga yang membedakan ruang-ruang selera telah menghasilkan setidaknya dua ruang, yaitu ruang pertama sering diistilahkan dengan "tasteful" yang menjadi ranah para desainer, sementara ruang kedua adalah "taste-free" dimana standar-standar baku desain tidak berlaku dan imun dari para desainer. Ruang-ruang dalam lingkup tasteful adalah ruang yang dianggap masyarakat memiliki legitimasi dan masuk kategori 'normal' saat penghakiman selera dilakukan untuk menentukan suatu lanskap itu indah atau jelek. Masyarakat secara umum menganggap bahwa ruang tasteful berada dalam ranah para arsitek lanskap, desainer taman, dan tukang taman amatir yang selalu memiliki target untuk menghadirkan dan menciptakan keindahan. Sementara ruang taste-free adalah di luar ranah penghakiman selera estetika, yang tidak seharusnya dikritik oleh para arsitek lanskap karena dianggap tidak pantas dan bahkan bertentangan.

\subsection{Industri Desain Lanskap}

Wacana yang berlaku dalam lingkar kelompok profesi arsitek lanskap adalah kami arsitek lanskap perlu melakukan langkah-langkah desain sama seperti yang dilakukan oleh lainnya, dan hanya kami - dalam kelompok kami - yang dapat melakukannya dengan baik dan selera yang bagus. Kalian yang yang tidak memiliki 'pengetahuan' dan 'selera' adalah orang 'luar', dengan kata lain bukan menjadi bagian dari kelompok. Pernyataan tersebut memiliki nuansa kuasa seperti yang dikonsepkan oleh Foucault mengenai kuasa dan pengetahuan yang acapkali muncul berdampingan (Barker, 2000:107-109; Sarup, 
2011:109-110). Mereka yang menguasai pengetahuan menjadi memiliki kuasa untuk menentukan mana selera yang bagus dan tidak, serta kemudian menggunakan hal tersebut untuk menghakimi yang berhak dan tidak berhak masuk dalam kelompok eksklusif penghakim selera. Kelompok arsitek lanskap tersebut sebagaimana teori Baudrillard mengatakan bahwa konsumsi membutuhkan manipulasi sinyal-sinyal secara aktif (dalam Featherstone, 2008), telah mengeluarkan sinyal-sinyal untuk mengklasifikasikan suatu desain taman sebagai memenuhi "kaidah estetika". Taman yang didesain oleh "sang arsitek lanskap" untuk dinikmati manusia telah memposisikan pengkelasan dalam manusia yang menggunakan taman tersebut. Muncullah ungkapan seperti, 'taman ini didesain oleh arsitek lanskap $X$ yang terkenal dengan ciri khas desainnya yang sangat memperhatikan lingkungan sekitar, dan seterusnya". Masyarakat digiring untuk masuk dalam selera kelas tertentu yang menunjukkan gaya hidup yang berbeda dengan 'orang kebanyakan'. Leiss (1978:19) dalam Featherstone (2008) mengatakan bahwa benda memiliki sifat simbolik yang dimanfaatkan dan dinegosiasikan untuk menegaskan berbagai perbedaan gaya hidup.

Tren desain lanskap adalah selera ephemeral yang umumnya berada di permukaan dan secara teoritis menutupi selera fundamental. la akan berubah dari waktu ke waktu dengan relatif cepat seperti tren busana. Demikian pula yang terjadi pada desain lanskap di Indonesia. Ada masa dimana tren desain taman mengikuti pola-pola organik 'natural' yang terjadi antara dekade 80 dan 90-an (Gambar 1). Sementara pada millennium 21 terjadi pergeseran tren desain taman pada pola-pola organik 'terkontrol' (Gambar 2). Tren ini dapat diamati dengan jelas di pulau Bali karena sebagai salah satu destinasi wisata dunia, perkembangan 'selera' arsitek lanskap dalam desain taman di hotel-hotel dan resorresor di Bali dapat diamati dengan cukup jelas.

Selera desain dimasing-masing era banyak ditentukan dan dipengaruhi oleh arsitekarsitek lanskap yang 'menempatkan' diri sebagai 'supir kendaraan' desain lanskap yang mengarahkan dan membawa obyek-obyek desainnya dalam kelas selera yang dibentuknya. Supir-supir desain tersebut membawa desain taman ke ranah industri yang membuat suatu desain diproduksi dan direproduksi terus menerus. Kondisi itu menurut Baudrillard (1983) dalam Featherstone (2008) membuat suatu produksi menjadi aktivitas reproduksi untuk mereduplikasi sinyal, image, dan simulasi yang terjadi terus menerus sehingga menghapuskan batas-batas antara image dan realitas. Apa yang terjadi pada desain taman di hotel-hotel dan resor di Bali menunjukkan gejala yang sama, yaitu penciptaan citra "Taman Tradisional Bali" yang sebenarnya dikonstruksi oleh para arsitek lanskap tersebut. Produk desain mereka direduplikasi oleh arsitek-arsitek lanskap lain dan tukang taman amatir yang mendesain di Bali dan menjadikannya keniscayahan "Taman Bali". Realitas desain taman dan lanskap Bali dilepaskan dari anggota komunitas anggota dan pendukung budaya Bali itu sendiri. Bahkan dalam beberapa kasus terjadi anggota komunitas "non-arsitek" untuk membuat desain sesuai standar arsitek lanskap demi masuk dalam kelas'elit' yang paham estetika taman Bali. 


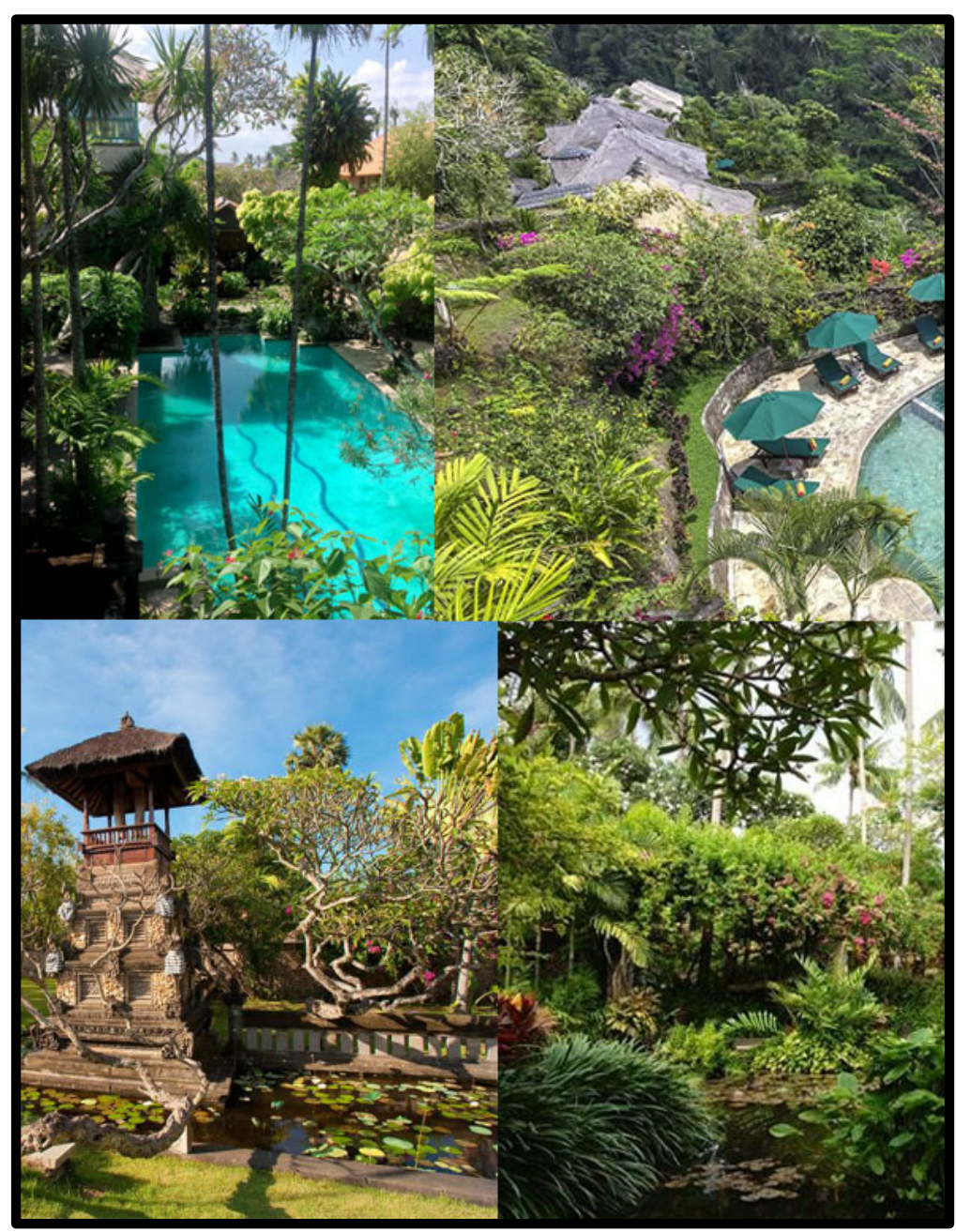

Gambar 1. Desain Taman Pola 'Natural' Sumber: dari berbagai sumber daring

Proses individu-individu pelaku desain lanskap mengasosiakan diri pada kelas desain tertentu yang terjadi di Bali telah mengantarkan desain taman di Bali dalam perangkap industri budaya. Sebenarnya bukan hanya para arsitek lanskap yang masuk dalam perangkap tersebut, bahkan para pemilik modal yang menggarap kerja taman dan lanskap telah masuk dalam perangkap. Kapitalisme dengan kuasa absolutnya telah mendikte karya-karya desain taman masuk dalam budaya massa. Seperti yang dikatakan Horkheimer dan Adorno (2014) bahwa kebudayaan massa adalah identik dan garis-garis kerangka artifisialnyanya ditunjukkan. Desain-desain taman hotel dan resor dipaksakan untuk memenuhi 'standar-standar' yang menjadi panduan duplikasi produk. Standarisasi dan duplikasi bahkan terjadi dan dilembagakan dalam proses pendidikan arsitektur lanskap. Terjadi reproduksi massa pelaku-pelaku desain yang nantinya diterjunkan dalam industri desain lanskap. Secara teknis dapat dikatakan bahwa proses produksi industri budaya dalam konteks desain lanskap terjadi mulai dari hulu ke hilir. 


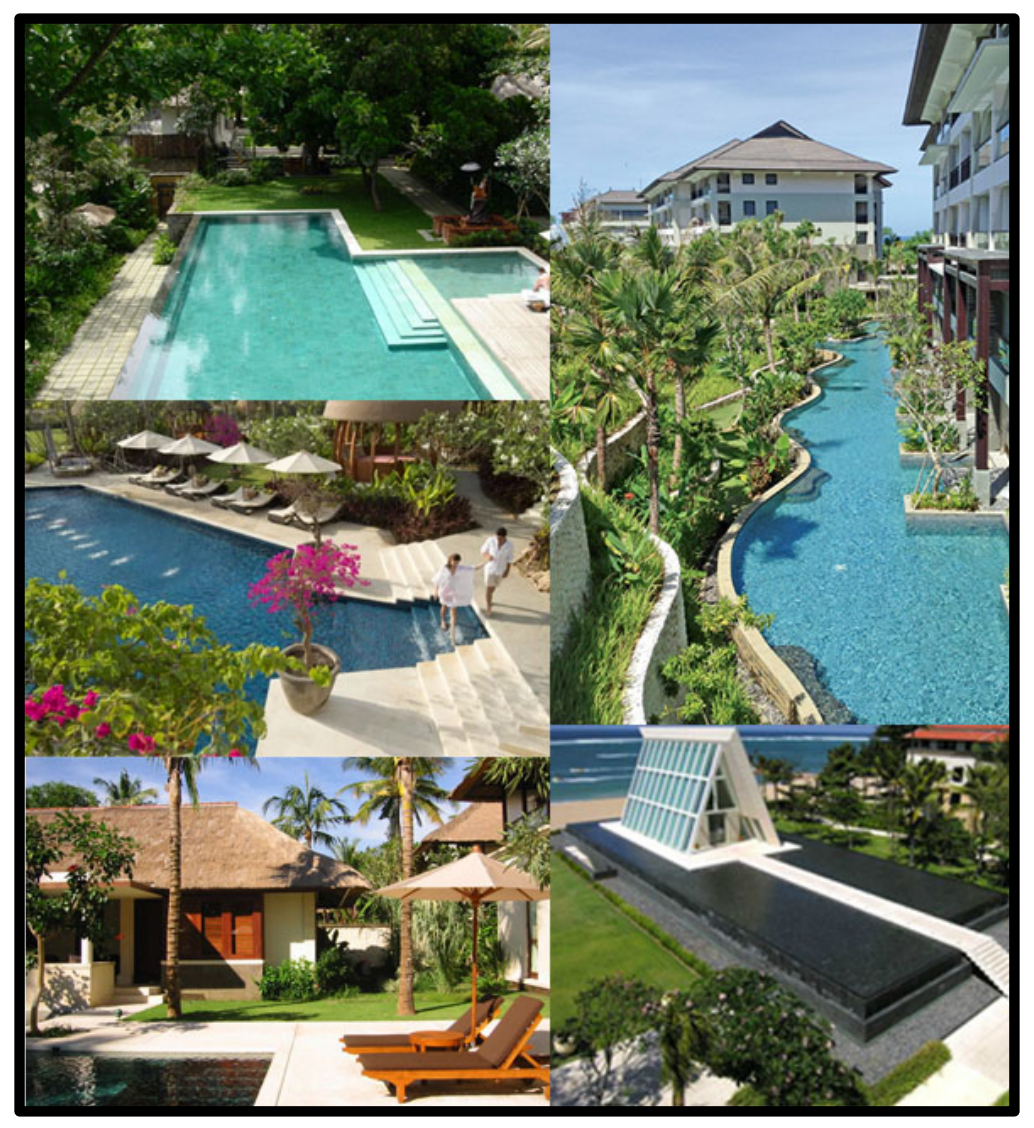

Gambar 2. Desain Taman Pola 'Terkontrol'

Sumber: dari berbagai sumber daring

\section{Kesimpulan}

Desain lanskap di era posmoderm tidak lepas dari perangkap industri budaya. Produk desain yang sejatinya bersifat pribadi dan bebas nilai ternyata tak berdaya menghadapi kapitalisme yang secara kuat mengendalikan kehidupan manusia. Budaya konsumen telah menggiring selera-selera manusia dalam kelas-kelas tertentu yang disebutkan oleh Treib dalam konteks desain lanskap sebagai ruang tasteful dan ruang taste-free. Arsitek-arsitek lanskap yang menciptakan ruang pengkelasan selera dan sekaligus memicu terjadinya budaya massa berupa desain taman yang menduplikasi tema yang popular di masyarakat. Kapitalisme bersama-sama dengan konsumen pengguna taman juga mendorong reproduksi desain yang berulang-ulang dengan tema-tema yang mirip atau dapat dikatakan identik.

Selera desain lanskap yang ephemeral silih berganti mengalir di permukaan, berubah sesuai tren. Sementara selera fundamental yang secara teoritis menetap dalam budaya tidak berani tampil, seperti selera yang mengalami dormansi. Konsep dormansi, meminjam istilah biologi tanaman, mengarahkan tumbuh berkembangnya selera fundamental untuk muncul hanya apabila ia menemukan atau diberikan media yang memadai dan sesuai. 


\section{DaftarPustaka}

Barker, C. 2000. Cultural Studies: Teori dan Praktik. Bentang, Yogyakarta.

Bourdieu, Pierre. 1996. Distinction: A Social Critique of The Judgment of Taste. Cambridge Massachusetts : Havard University Press

Damajani, R.R.D. dan D. Larasati. 2010. Wacana Desain: Karya dan Pemikiran Imam Buchori Zainuddin. Penerbit ITB, Bandung.

Featherstone, M. 2008. Posmodernisme dan Budaya Konsumen. M.Z. Elizabeth (penterjemah). Cetakan ke-3. Pustaka Pelajar, Yogyakarta.

Horkheimer, M dan T.W. Adorno. 2014. Dialektika Pencerahan. A. Sahidah (penterjemah). IRCiSoD, Yogyakarta.

Jackson, J.B. 1980. The Necessity for Ruins. The University of Massachusetts Press, Amherst.

Sarup, M. 2011. Panduan Pengantar untuk Memahami Postrukturalisme \& Posmodernisme. M.A. Hidayat (penterjemah). Cetakan ke-2. Jalasutra, Yogyakarta.

Treib, M. 1993. Modern Landscape Architecture: A Critical Review. The MIT Press, Cambridge-Massachusetts.

Whythe, I.D. 2002. Landscape History Since 1500. Reaktion Books, Ltd., London. 